\begin{tabular}{|c|c|c|}
\hline (j) & $\begin{array}{c}\text { Türkiye Tarımsal Araştırmalar Dergisi } \\
\text { dergipark.org.tr/tutad }\end{array}$ & $\begin{array}{l}\text { Turk J Agric Res } \\
\text { 2019, 6(2): 214-221 } \\
\text { @ TÜTAD } \\
\text { ISSN: 2148-2306 }\end{array}$ \\
\hline $\begin{array}{l}\text { UNIVERSiTESI } \\
\text { Bulimin 1suämata }\end{array}$ & Research Article & $\begin{array}{l}\text { e-ISSN: } 2528-858 X \\
\text { doi: } 10.19159 / \text { tutad.559617 }\end{array}$ \\
\hline
\end{tabular}

\title{
Influence of L-Tryptophan and Melatonin on Germination of Onion and Leek Seeds at Different Temperatures
}

\author{
Fatih HANCI*, Mehmet ÇINGI, Hakan AKINCI \\ Erciyes University, Agriculture Faculty, Department of Horticulture, Kayseri, TURKEY
}

\begin{tabular}{|c|c|}
\hline Received: 01.05 .2019 & Accepted: 29.06 .2019 \\
\hline \multicolumn{2}{|c|}{ ORCID ID (By author order) } \\
\hline (1D) orcid.org/0000-0002-2015-0351 (1) orcid.org/0000-0001-803 & id.org/0000-0003-1138-716X \\
\hline
\end{tabular}

\begin{abstract}
The aim of the study was to evaluate the influence of different L-tryptophan and melatonin concentrations on several germination parameters of onion and leek seeds under low and high-temperature conditions. The experiments were carried out in laboratories of the Erciyes University. Seeds were treated with 125, 250, 375 ppm L-Tryptophan and 5, 10, 25 $\mathrm{uM}$ Melatonin for 24 hours, then subjected to germination tests at optimum $\left(21^{\circ} \mathrm{C}\right)$ chilling stress $\left(7^{\circ} \mathrm{C}\right)$ and hot temperature $\left(35^{\circ} \mathrm{C}\right)$ conditions. Seeds not treated were considered as controls. Treatment of onion seeds with $125 \mathrm{ppm}$ L-tryptophan had a significantly positive effect on final germination ratio at $7{ }^{\circ} \mathrm{C}$ while in leek seeds, the $5 \mu \mathrm{M}$ concentration of melatonin had a significant effect on the germination index at the same temperature. In both Allium species, hormone treatments had no effect on mean germination time. These values decreased depending on the increase in temperature. The extreme level of high temperature burned certain percent of seedlings, while at low temperature, seedlings were not harmed by cold domination.
\end{abstract}

Keywords: L-Tryptophan, melatonin, onion, leek, germination

\section{Introduction}

Especially after sowing in the early spring or autumn, slow and non-homogeneous germination, as well as a high number of abnormal seedlings, have been observed as a result of stress conditions (Borowski and Michalek, 2006). Also, compared to many vegetable crops, onion has quite shortlived seeds (Amjad and Anjum, 2002). This causes the onion seeds to be generally expensive (Black et al., 2006). For this reason, there has been a great interest to research practical and affordable techniques to improve seed germination, growth, and yield of onion plants (De Souza et al., 2014).

Pre-applications to increase seed germination are called as "seed priming". These applications also help to grow normal and vigorous seedlings. This makes the plants more resistant to biotic and abiotic stress conditions (Khan et al., 2009a). The use of plant growth regulators in the course of priming and other pre-sowing treatments can improve germination performance of many crops
(Khan et al., 2009b). Small polycationic molecules, called polyamines, can be found in varying amounts in almost all organisms. Functions of the polyamines have been reported in several biological processes such as transcription, RNA alteration, protein synthesis and the modulation of enzyme activities (Takahashi and Kakehi, 2010). Polyamines are important for growth, development and cell growth in plants, can be accumulated in tissues and can undertake various functions under stress conditions. Polyamine type, concentration, and status of embryo dormancy can affect the germination of the seed (Farooq et al., 2011). Melatonin (N-acetyl-5-methoxytryptamine, MEL) is one of the best-studied biological molecules found in the cattle pineal gland in 1958 (Lerner et al., 1958). Since the detection of MEL in a single-cell photosynthetic organism Gonyaulax polyedra in the early 1990s (Hattori et al., 1995), research in plants has been continuing. In contrast to animals, the role of MEL in plants is less understood. Many 
studies have proposed that MEL can play a role as a plant growth regulator and bio-stimulator under stress conditions (Arnao and Hernandez-Ruiz, 2006). Application of MEL has increased germination performance of cucumber, Phacelia tanacetifolia, and pepper, (Posmyk et al., 2009; Tiryaki and Keleş, 2012; Korkmaz et al., 2017; Zhang et al., 2017).

L-tryptophan (3-indolylalanine, L-T) was first discovered by English chemist Frederick Gowland Hopkins in 1901. It is an essential amino acid not only for plants but also for animals, humans, and some bacteria (Frankenberger and Arshad, 1991). L-T which bearing an indole ring is a unique amino acid (Palego et al., 2016). It is a biologically active precursor of auxin, which, when applied exogenously, increases the levels of auxin in plant tissues. A positive response of L-T application in germination and growth performance of several crops has been reported by different researchers (Khodary, 1992; Parvez et al., 2000; Abbas et al., 2013; Antony et al., 2017).

Although numerous reports have been published to the investigation of the effects of different plant growth regulators in onion and leek seeds, any research has not been conducted to detect the role of L-T or MEL treatment on germination characteristics under stress conditions. Thus, the aim of this study was to evaluate the effect of different concentration of L-T and MEL on the several germination parameters of onion and leek seeds under low and high-temperature conditions.

\section{Materials and Methods}

This study was carried out in laboratories of the Erciyes University, in 2019. The onion seeds (Allium cepa L.cv. Valenciana) and leek seeds (Allium porrum L.cv. İnegöl-92) were provided by a local seller. The seeds were surface sterilized under aseptic conditions with $70 \%$ ethanol for 1 min, followed by $20 \%$ commercial Clorox $(5.25 \%$ sodium hypochlorite) for $10 \mathrm{~min}$. and then washed 2 to 3 times with distilled water (Hanci et al., 2012). The germination tests are designed according to Anonymous (1999) rules. Following disinfestation, seeds were soaked $20 \mathrm{~mL}$ of 0 (distilled water), 125, 250, 375 ppm L-T; and 5, 10 , and $25 \mu \mathrm{M}$ MEL solutions at $20^{\circ} \mathrm{C}$ in darkness for 24 hours (Karaca, 2013). After treatment, seeds were rinsed under running water for 2 minutes and were kept to dry on paper towels for 4 hours. Then fifty seeds were placed on two layers of filter paper moistened with $5 \mathrm{~mL}$ of distilled water in covered $10 \mathrm{~cm}$ Petri dishes. A completely randomized design was used with four replications. Although germination experiments in ISTA (International Seed Testing Association) rules have been limited to 12 days for onion and leek, this period was considered as 21 days, as it was assumed that low temperature would prolong germination time. The Petri dishes were placed in a germination chamber in the dark at various temperatures $\left(7^{\circ} \mathrm{C}, 21^{\circ} \mathrm{C}\right.$, and $\left.35^{\circ} \mathrm{C}\right)$ for 21 days. Germinated seeds (with a protruded radicle of 2 $\mathrm{mm}$ long) were counted daily and conserved until end of the experiment. At the end of the study, Equations 1, 2, 3, and 4 were used to determine the effects of L-T and MEL on the germination of seeds (Al-Maskri et al., 2004; Li et al., 2007; Mercedes et al., 2007).

$$
\begin{gathered}
\text { G-max }=\text { Germination rate }(\%)=(G / T) \times 100(1) \\
\text { G-index }=\text { Germination Index }=(1 \text {. day } G \text {-max } / \\
D t 1)+\ldots \ldots \ldots \ldots+(n \text {. day } G-\max / D t n) \\
\text { G50 (day) }=\text { Time for germination of } 50 \%
\end{gathered}
$$
seeds

MGT $=$ Mean germination time $($ Day $)=[(1$ day $G \times 1)+\ldots \ldots . .+(n$. day $G \times n)] /$ Total $G$

Where $T$ is the total seed number; $G$ number of seeds which were germinated on the day; $G t$ number of days counted from the beginning of germination. Statistical analysis was conducted using the PAST3 software (Hammer et al., 2001). The data from the experiment were subjected to a general analysis of variance (ANOVA).

\section{Results}

\subsection{Experiment I, Onion}

The germination percentage (G-max, \%), germination index (G-index) and shoot length (SL, $\mathrm{cm}$ ) were significant for three factors (treatment, temperature, and their interaction). Fresh weight (FW, mg) was significant for both treatment and temperature; mean germination time (MGT, day) was for only temperature. The effects of pretreatments on onion seeds are shown in Table 1 and 2. Germination was very low at $7{ }^{\circ} \mathrm{C}$ and 35 ${ }^{\circ} \mathrm{C}$, with $20.95 \%$ and $21.19 \%$, respectively.

In addition, at $21{ }^{\circ} \mathrm{C}$, it has been found interesting that some treatments reduce the germination rates. The seeds incubated at $21{ }^{\circ} \mathrm{C}$ degrees and not treated with hormones germinated at a $93.33 \%$ rate. All seeds were germinated at 21 ${ }^{\circ} \mathrm{C}$ after 125 ppm L-T treatment (100\%). However, increasing doses of L-T decreased the germination rate sharply at this temperature. This has also been observed for MEL treatments. However, the sharp decrease in MEL applied seeds was observed in the first dose. Under extreme temperature conditions $\left(7^{\circ} \mathrm{C}\right.$ and $\left.35^{\circ} \mathrm{C}\right)$ the lowest doses used 
Table 1. Some germination features of onion seeds at different temperatures ${ }^{1}$

\begin{tabular}{|c|c|c|c|c|c|}
\hline $\begin{array}{l}\text { Temperature } \\
\left({ }^{\circ} \mathrm{C}\right)\end{array}$ & Treatment & $\begin{array}{c}\text { G-max } \\
(\%)\end{array}$ & $\begin{array}{l}\text { G-50 } \\
\text { (day) }\end{array}$ & G-Index & $\begin{array}{c}\mathrm{SL} \\
(\mathrm{cm})\end{array}$ \\
\hline \multirow{7}{*}{7} & Control & $30.00 \mathrm{c}-\mathrm{f}$ & $19.33 \mathrm{ab}$ & $1.56 \mathrm{f}$ & $0.43 \mathrm{e}$ \\
\hline & 125 ppm L-T & $35.00 \mathrm{~cd}$ & $18.66 \mathrm{ab}$ & $1.86 \mathrm{f}$ & $0.43 \mathrm{e}$ \\
\hline & $250 \mathrm{ppm} \mathrm{L-T}$ & $23.33 \mathrm{c}-\mathrm{g}$ & $20.00 \mathrm{a}$ & $1.18 \mathrm{f}$ & $0.37 \mathrm{e}$ \\
\hline & 375 ppm L-T & $15.00 \mathrm{e}-\mathrm{g}$ & $19.00 \mathrm{ab}$ & $0.76 \mathrm{f}$ & $0.30 \mathrm{e}$ \\
\hline & $5 \mu \mathrm{M}$ MEL & $13.33 \mathrm{f}-\mathrm{g}$ & $17.00 \mathrm{~b}$ & $0.82 \mathrm{f}$ & $0.30 \mathrm{e}$ \\
\hline & $10 \mu \mathrm{M}$ MEL & $11.67 \mathrm{~g}$ & $20.00 \mathrm{a}$ & $0.61 \mathrm{f}$ & $0.20 \mathrm{e}$ \\
\hline & $25 \mu \mathrm{M}$ MEL & $18.33 \mathrm{~d}-\mathrm{g}$ & $18.33 \mathrm{ab}$ & $0.97 \mathrm{f}$ & $0.27 \mathrm{e}$ \\
\hline \multirow{7}{*}{21} & Control & $93.33 \mathrm{a}$ & $3.67 \mathrm{e}$ & $22.79 \mathrm{a}$ & $7.67 \mathrm{a}$ \\
\hline & 125 ppm L-T & $100 \mathrm{a}$ & $3.67 \mathrm{e}$ & $20.93 \mathrm{a}$ & $9.00 \mathrm{a}$ \\
\hline & $250 \mathrm{ppm} \mathrm{L}-\mathrm{T}$ & $63.33 \mathrm{~b}$ & $4.33 \mathrm{de}$ & $12.99 \mathrm{~b}$ & $7.33 \mathrm{ab}$ \\
\hline & 375 ppm L-T & $23.33 \mathrm{c}-\mathrm{g}$ & $4.00 \mathrm{e}$ & $4.67 \mathrm{~d}-\mathrm{f}$ & $3.67 \mathrm{~d}$ \\
\hline & $5 \mu \mathrm{M}$ MEL & $36.66 \mathrm{c}$ & $6.67 \mathrm{~d}$ & $8.96 \mathrm{~b}-\mathrm{e}$ & $4.67 \mathrm{~cd}$ \\
\hline & $10 \mu \mathrm{m}$ MEL & $21.66 \mathrm{c}-\mathrm{g}$ & $4.00 \mathrm{e}$ & $4.56 \mathrm{~d}-\mathrm{f}$ & $5.67 \mathrm{bc}$ \\
\hline & $25 \mu \mathrm{M}$ MEL & $21.66 \mathrm{c}-\mathrm{g}$ & $11.00 \mathrm{c}$ & $4.25 \mathrm{ef}$ & $4.00 \mathrm{~cd}$ \\
\hline \multirow{7}{*}{35} & Control & $25.00 \mathrm{c}-\mathrm{g}$ & $2.33 \mathrm{e}$ & $10.06 \mathrm{bc}$ & $0.33 \mathrm{e}$ \\
\hline & 125 ppm L-T & $33.33 \mathrm{~cd}$ & $2.00 \mathrm{e}$ & $11.68 \mathrm{bc}$ & $0.67 \mathrm{e}$ \\
\hline & 250 ppm L-T & $18.33 \mathrm{~d}-\mathrm{g}$ & $2.00 \mathrm{e}$ & $7.51 \mathrm{c}-\mathrm{e}$ & $0.30 \mathrm{e}$ \\
\hline & 375 ppm L-T & $25.00 \mathrm{c}-\mathrm{g}$ & $2.67 \mathrm{e}$ & $7.51 \mathrm{c}-\mathrm{e}$ & $0.30 \mathrm{e}$ \\
\hline & $5 \mu \mathrm{M}$ MEL & $20.00 \mathrm{c}-\mathrm{g}$ & $3.33 \mathrm{e}$ & $5.04 \mathrm{~d}-\mathrm{f}$ & $0.20 \mathrm{e}$ \\
\hline & $10 \mu \mathrm{m}$ MEL & $15.00 \mathrm{e}-\mathrm{g}$ & $4.00 \mathrm{e}$ & $4.59 \mathrm{~d}-\mathrm{f}$ & $0.20 \mathrm{e}$ \\
\hline & $25 \mu \mathrm{M}$ MEL & $11.67 \mathrm{~g}$ & $2.00 \mathrm{e}$ & $5.00 \mathrm{~d}-\mathrm{f}$ & $0.23 \mathrm{e}$ \\
\hline
\end{tabular}

Ratios (Hormone, Temperature, Hormone x Temperature): G-Max: 19.8*, 63.6*, 6.5*; G50: 667.01* $2.21^{\text {ns }}, 4.56^{*} ;$ G-Index: 13.4 ${ }^{\text {ns }}, 66.9^{*}, 5.8^{*}$; SL: $3.9^{*}, 181.8^{*}, 3.1^{*}$. *significant $(\mathrm{p}<0.01)$, ns: not significant. F: Freedom, L-T: L-tryptophan, MEL: Melatonin, G-max: Final germination percentage, G-index: Germination index, G-50: Time for germination of 50\% seeds, SL: Shoot length. Means within a group that have a different small letter are significantly different from each other.

Table 2. MGT and seedlings FW of onion at different temperatures

\begin{tabular}{|c|c|c|c|c|c|c|c|c|}
\hline & \multicolumn{8}{|c|}{ MGT (day) } \\
\hline $\begin{array}{l}\text { Temperature } \\
\left({ }^{\circ} \mathrm{C}\right)\end{array}$ & Control & $\begin{array}{l}125 \mathrm{ppm} \\
\mathrm{L}-\mathrm{T}\end{array}$ & $\begin{array}{l}250 \mathrm{ppm} \\
\mathrm{L}-\mathrm{T}\end{array}$ & $\begin{array}{c}375 \mathrm{ppm} \\
\mathrm{L}-\mathrm{T}\end{array}$ & $\begin{array}{l}5 \mu \mathrm{M} \\
\mathrm{MEL} \\
\end{array}$ & $\begin{array}{c}10 \mu \mathrm{M} \\
\mathrm{MEL}\end{array}$ & $\begin{array}{c}25 \mu \mathrm{M} \\
\mathrm{MEL}\end{array}$ & Average \\
\hline 7 & 19.26 & 19.05 & 19.59 & 19.63 & 17.33 & 12.83 & 19.08 & $18.11 \mathrm{a}$ \\
\hline 21 & 5.87 & 7.55 & 8.16 & 7.28 & 6.76 & 6.61 & 10.90 & $7.59 \mathrm{~b}$ \\
\hline 35 & 2.81 & 4.21 & 3.22 & 2.93 & 4.75 & 6.00 & 2.44 & $3.76 \mathrm{c}$ \\
\hline \multirow[t]{2}{*}{ Average } & 9.31 & 10.27 & 10.32 & 9.95 & 9.61 & 8.48 & 10.81 & \\
\hline & \multicolumn{8}{|c|}{ FW (mg) } \\
\hline $\begin{array}{l}\text { Temperature } \\
\left({ }^{\circ} \mathrm{C}\right)\end{array}$ & Control & $\begin{array}{l}125 \mathrm{ppm} \\
\text { L-T }\end{array}$ & $\begin{array}{c}250 \mathrm{ppm} \\
\mathrm{L}-\mathrm{T}\end{array}$ & $\begin{array}{l}375 \text { ppm } \\
\text { L-T }\end{array}$ & $\begin{array}{l}5 \mu \mathrm{M} \\
\mathrm{MEL}\end{array}$ & $\begin{array}{l}10 \mu \mathrm{M} \\
\mathrm{MEL}\end{array}$ & $\begin{array}{c}25 \mu \mathrm{M} \\
\text { MEL }\end{array}$ & Average \\
\hline 7 & 21.96 & 25.18 & 26.41 & 21.09 & 22.42 & 22.55 & 25.59 & $23.60 \mathrm{a}$ \\
\hline 21 & 21.57 & 24.14 & 25.39 & 20.33 & 20.69 & 20.56 & 24.67 & $22.48 \mathrm{~b}$ \\
\hline Average & $21.76 \mathrm{C}$ & $24.66 \mathrm{~B}$ & $25.90 \mathrm{~A}$ & $20.71 \mathrm{D}$ & $21.55 \mathrm{C}$ & $21.55 \mathrm{C}$ & 25.13 & \\
\hline
\end{tabular}

in L-T applications increased germination rates compared to the control. No effect was observed in MEL applications at these temperatures. The lowest germination index value was observed at 7 ${ }^{\circ} \mathrm{C}$. There was no statistical difference between the results obtained from all treatments at this temperature. The smallest shoot length values were also observed at this temperature. In terms of shoot lengths, at $21{ }^{\circ} \mathrm{C}, 125 \mathrm{ppm} \mathrm{L}-\mathrm{T}$ pre-treatment gave the highest value but there was no statistically significant difference with the control group.

Only the "temperature" had an effect on the MGT of the seeds. The MGT was reduced by increased temperature (Table 2). When evaluating the fresh weight of the shoots, the values obtained at $35{ }^{\circ} \mathrm{C}$ were not taken into account because the shoots formed at this temperature were dried before the end of the experiment. The highest shoot fresh weights were obtained from $250 \mathrm{ppm}$ L-T and $25 \mu \mathrm{M}$ MEL pre-treatments.

\subsection{Experiment II, Leek}

According to the results, the differences were statistically significant depending on the temperature. Only the differences between the results of G-max and results of G-index were found to be significant depending on hormone 
applications. Among seeds not pre-treated with L-T or MEL, the highest germination (G-max $100 \%$ ) was observed at $21^{\circ} \mathrm{C}$ (Table 3 ).

Considering the tested L-T and MEL pretreatments, all concentrations had the favorable effect on germination $(100 \%)$ at $21{ }^{\circ} \mathrm{C}$, although, this effect was observed only at $125 \mathrm{ppm} \mathrm{L}-\mathrm{T}$ and $5 \mu \mathrm{M}$ MEL concentration during the $7{ }^{\circ} \mathrm{C}$ incubation (Table 4). At this temperature, increasing doses of hormones had a negative effect on the germination rate. The lowest germination rates in all applications were observed in seeds incubated at $35^{\circ} \mathrm{C}$ degrees. The percentage of seed germination decreased in accordance with further increments in the L-T and MEL concentration at this temperature compared to control.

Germination index was very low at $7{ }^{\circ} \mathrm{C}$ and 35 ${ }^{\circ} \mathrm{C}$ with $2.45 \%$ and $3.73 \%$, respectively. Increasing doses of L-T had no effect on germination index at $7{ }^{\circ} \mathrm{C}$ and $21{ }^{\circ} \mathrm{C}$, however, a small increase was observed at $35{ }^{\circ} \mathrm{C}$ depending on increasing concentrations of L-T. The lowest concentration of MEL had a positive effect on germination index.

The highest mean germination time was observed at $7{ }^{\circ} \mathrm{C}$ (17.26 day). There was no statistical difference between the results obtained from other temperatures (Table 4). A sharp reduction was observed at extreme temperature, which is evidenced significantly. No hormonal effect was observed on this feature.

\section{Discussion}

The results of the study showed that pre-treatment with L-T and MEL at low temperature may affect the seed germination of onions and leeks. Germination is slowing at low temperature and the germination time is prolonged (Grime et al., 1981). This could be related to the oxygen permeability via seed coat (Come and Tissaoui, 1973) or the effect of temperature on water uptake (Gulliver and Heydecker, 1973). In a study of onion seeds, it has been reported that increasing the temperature from $5{ }^{\circ} \mathrm{C}$ to $30{ }^{\circ} \mathrm{C}$ causes a rapid increase in the percentage of germination in both light and dark conditions (Abu-Rayyan, 2012). In our study, incubation at the $21{ }^{\circ} \mathrm{C}$ increased the germination index compared to $7{ }^{\circ} \mathrm{C}$ and $35^{\circ} \mathrm{C}$ conditions for both onion and leek seeds. Raising the temperature above $7{ }^{\circ} \mathrm{C}\left(21\right.$, and $\left.35^{\circ} \mathrm{C}\right)$ caused a rapid decrease in days to $50 \%$ germination in both L-T and MEL pre-treatments. At $7{ }^{\circ} \mathrm{C}, 50 \%$ germination of seeds were achieved at $17^{\text {th }}$ day in onion seeds. This could be related to the oxygen permeability via

Table 3. Some germination features of leek seeds at different temperatures

\begin{tabular}{|c|c|c|c|c|c|}
\hline $\begin{array}{l}\text { Temperature } \\
\left({ }^{\circ} \mathrm{C}\right)\end{array}$ & Hormones & $\begin{array}{c}\text { G-max } \\
(\%)\end{array}$ & $\begin{array}{c}\text { G-50 } \\
\text { (days) }\end{array}$ & $\begin{array}{l}\text { MGT } \\
\text { (days) }\end{array}$ & $\begin{array}{c}\mathrm{SL} \\
(\mathrm{cm})\end{array}$ \\
\hline \multirow{8}{*}{7} & Control & 38.33 & 16.67 & 16.68 & 0.83 \\
\hline & 125 ppm L-T & 48.33 & 16.33 & 16.65 & 0.83 \\
\hline & 250 ppm L-T & 35.00 & 17.33 & 17.69 & 0.70 \\
\hline & 375 ppm L-T & 36.67 & 16.67 & 17.02 & 0.63 \\
\hline & $5 \mu \mathrm{M}$ MEL & 55.00 & 18.67 & 17.27 & 0.70 \\
\hline & $10 \mu \mathrm{M}$ MEL & 33.33 & 18.00 & 17.76 & 0.70 \\
\hline & $25 \mu \mathrm{M}$ MEL & 36.67 & 17.67 & 17.77 & 0.67 \\
\hline & Average & $40.48 \mathrm{~b}$ & $17.33 \mathrm{a}$ & $17.26 \mathrm{a}$ & $0.72 \mathrm{~b}$ \\
\hline \multirow{8}{*}{21} & Control & 100.00 & 3.00 & 3.57 & 9.67 \\
\hline & 125 ppm L-T & 100.00 & 3.00 & 3.85 & 10.33 \\
\hline & 250 ppm L-T & 100.00 & 3.33 & 4.02 & 11.67 \\
\hline & 375 ppm L-T & 100.00 & 3.33 & 3.78 & 7.33 \\
\hline & $5 \mu \mathrm{M}$ MEL & 100.00 & 3.33 & 3.93 & 8.00 \\
\hline & $10 \mu \mathrm{M}$ MEL & 96.67 & 3.67 & 4.27 & 9.00 \\
\hline & $25 \mu \mathrm{M}$ MEL & 100.00 & 3.33 & 4.72 & 9.00 \\
\hline & Average & $99.52 \mathrm{a}$ & $3.29 \mathrm{~b}$ & $4.02 \mathrm{~b}$ & $9.29 \mathrm{a}$ \\
\hline \multirow{8}{*}{35} & Control & 21.67 & 4.33 & 4.44 & 0.20 \\
\hline & 125 ppm L-T & 8.33 & 3.67 & 4.83 & 0.20 \\
\hline & $250 \mathrm{ppm} \mathrm{L-T}$ & 11.67 & 3.33 & 10.89 & 0.30 \\
\hline & 375 ppm L-T & 13.33 & 3.00 & 3.58 & 0.20 \\
\hline & $5 \mu \mathrm{M}$ MEL & 18.33 & 3.67 & 3.50 & 0.20 \\
\hline & $10 \mu \mathrm{M}$ MEL & 10.00 & 4.00 & 6.83 & 0.20 \\
\hline & $25 \mu \mathrm{M}$ MEL & 16.67 & 5.67 & 6.97 & 0.33 \\
\hline & Average & $14.29 \mathrm{c}$ & $3.95 \mathrm{~b}$ & $5.87 \mathrm{~b}$ & $0.23 \mathrm{~b}$ \\
\hline
\end{tabular}


Table 4. Some germination features of leek seeds at different temperatures

\begin{tabular}{|c|c|c|c|}
\hline Hormones & Temperatures $\left({ }^{\circ} \mathrm{C}\right)$ & G-index & FW (mg) \\
\hline \multirow{4}{*}{ Control } & 7 & 2.43 & 2.26 \\
\hline & 21 & 30.29 & 2.13 \\
\hline & 35 & 5.61 & \\
\hline & Average & $12.78 \mathrm{a}$ & $2.20 \mathrm{c}$ \\
\hline \multirow{4}{*}{125 ppm L-T } & 7 & 3.04 & 2.61 \\
\hline & 21 & 29.83 & 2.44 \\
\hline & 35 & 2.22 & \\
\hline & Average & $11.70 \mathrm{abc}$ & $2.52 \mathrm{~b}$ \\
\hline \multirow{4}{*}{250 ppm L-T } & 7 & 2.11 & 2.67 \\
\hline & 21 & 27.98 & 2.62 \\
\hline & 35 & 3.37 & \\
\hline & Average & $11.15 \mathrm{bc}$ & $2.64 \mathrm{a}$ \\
\hline \multirow{4}{*}{375 ppm L-T } & 7 & 2.24 & 2.26 \\
\hline & 21 & 29.94 & 2.06 \\
\hline & 35 & 3.87 & \\
\hline & Average & $12.02 \mathrm{ab}$ & $2.16 \mathrm{c}$ \\
\hline \multirow{4}{*}{$5 \mu \mathrm{M}$ MEL } & 7 & 3.26 & 2.15 \\
\hline & 21 & 30.35 & 2.20 \\
\hline & 35 & 5.35 & \\
\hline & Average & $12.99 \mathrm{a}$ & $2.18 \mathrm{c}$ \\
\hline \multirow{4}{*}{$10 \mu \mathrm{M}$ MEL } & 7 & 1.93 & 2.30 \\
\hline & 21 & 26.89 & 2.16 \\
\hline & 35 & 2.42 & \\
\hline & Average & $10.41 \mathrm{c}$ & $2.23 \mathrm{c}$ \\
\hline \multirow{4}{*}{$25 \mu \mathrm{M}$ MEL } & 7 & 2.12 & 2.65 \\
\hline & 21 & 26.44 & 2.59 \\
\hline & 35 & 3.26 & \\
\hline & Average & $10.60 \mathrm{bc}$ & $2.62 \mathrm{ab}$ \\
\hline
\end{tabular}

F Ratios (Hormone, Temperature, Hormone x Temperature): G-Index: $3.2^{*}, 1635.3^{*}, 0.9^{\text {ns }} ;$ FW: $37.5^{*}, 13.5^{*}, 1.4^{\text {ns }}$. *: Significant (p < 0.01), ns: Not significant, F: Freedom, L-T: L-tryptophan, MEL: Melatonin, G-index: Germination index, FW: Fresh weight of shoot, Means within a group that have a different small letter are significantly different from each other

seed coat (Come and Tissaoui, 1973) or the effect of temperature on water uptake (Gulliver and Heydecker, 1973). Pimpini et al. (1993) reported that very low germination rate was induced by temperature levels below $7.5{ }^{\circ} \mathrm{C}$. In addition, a result of slow water imbibition, while at optimum temperature, a relation was observed between water uptake and oxygen availability. A highly statistical superiority was induced by the interaction of temperature and light showed this superiority just at $5{ }^{\circ} \mathrm{C}, 35^{\circ} \mathrm{C}$, and $40{ }^{\circ} \mathrm{C}$ which are unfavorable conditions to start germination (Fenner, 2000). Both onion and leek seeds had different responses to concentrations of L-T and MEL at different germination temperatures. L-T (especially $125 \mathrm{ppm}$ ) had a positive effect on the maximum germination rate of onion seeds at low temperature. At $21{ }^{\circ} \mathrm{C}$ temperature, the hormone applications did not increase the maximum germination rate and germination index.

The results of hormones of different concentrations applied to increase germination ratio and index of onion seeds at low and high temperatures showed that L-T was more effective than MEL. In terms of concentration, $125 \mathrm{ppm}$ was determined to be the most effective dose for $\mathrm{L}-\mathrm{T}$.
However, in leek seeds, $5 \mu \mathrm{M}$ MEL application was found to be more effective on germination rate at low temperature. Similar results were obtained from the study of Simlat et al. (2018). The mechanisms of the effect of MEL are not clearly understood, but all changes in plant metabolism occur because of its influence as an antioxidant, and its role in membrane stabilization and organizing of gene expression (Nawaz et al., 2016). However, some previous reports point out that the influence of MEL on seed germination bound up with on its concentration. Higher concentrations of MEL inhibited or had no influence on seed germination, whereas lower concentrations improved seed germination (Hernandez Ruiz et al., 2005; Chen et al., 2009; Wei et al., 2015). Zhang et al. (2013) reported that MEL had no effect on germination of cucumber seeds, regardless of the germination conditions. On the other hand, another report pointed to concentrations of 1- and 10-mM MEL appeared to have a beneficial effect on germination of red cabbage seeds under optimal conditions (Zhang et al., 2016). Also, Bajwa et al. (2014) reported that the exogenous MEL applying confers chilling tolerance in Arabidopsis. The effect of hormone 
applications on germination properties may vary depending on plant species. Similar results were obtained in Gibberellic acid $\left(\mathrm{GA}_{3}\right)$ which is one of the most investigated hormones on germination. For example, any germination were observed in Origanum husnucan-baseri seeds exposed to $\mathrm{GA}_{3}$ application in the study of Caniş (2006). Similarly, in a study on germination of Eranthis hyemalis L. seeds by Tipırdamaz and Gömürgen (2000), it was reported that application of $\mathrm{GA}_{3}$ was not effective on germination at $23{ }^{\circ} \mathrm{C}$. Nematollah et al. (2011) reported that $\mathrm{GA}_{3}$ applications did not affect the germination percentages of Allium hirtifolium seeds. In a study conducted with Datura stramonium L. seeds, it was reported that $\mathrm{GA}_{3}$ application significantly reduced germination (Kevseroğlu, 1993).

\section{Conclusions}

Although the positive effect of seed priming in MEL solutions on seed germination and plant quality, especially under stressful conditions, is well documented, reports that prove the positive effects of L-T is extremely limited. This is the first study investigating the effects of L-T and MEL on onion and leek under stress conditions.

The findings of this study show that the effects of the L-T and MEL are different for onion and leek seeds. The seeds of leek and onion incubated at $35^{\circ} \mathrm{C}$ were germinated faster compared to other temperatures. The effect of the L-T and MEL on the germination rate at low and high temperature has been limited. The application of 125 ppm LT increased the germination rate slightly in onion seeds incubated at low temperature. However, this effect was not observed in germination index values. In leek seeds, in addition to $125 \mathrm{ppm}$ LT, 5 $\mu \mathrm{L}$ MEL application increased the germination rate at low temperature. In both species, fresh weights of shoots obtained at low temperature were found to be higher. Our results suggest that pre-sowing with LT or MEL can be applied in agriculture to improve germination in onion and leek seeds. However, more extensive studies are needed to determine the appropriate doses.

\section{Acknowledgments}

This work was supported by Research Fund of the Erciyes University. Project Number: FLO-20188572 .

\section{References}

Abbas, S.H., Sohail, M., Saleem, M., Mahmood, T., Aziz, I., Qamar, M., Majeed, A., Arif, M., 2013. Effect of L-tryptophan on plant weight and pod weight in chickpea under rainfed conditions.
Science, Technology and Development, 32(4): 277 280.

Abu-Rayyan, A., 2012. Onion seed germination as affected by temperature and light, International Journal of Vegetable, 18(1): 49-65.

Al-Maskri, A.Y., Khan, M.M., Iqbal, M.J., Abbas, M., 2004. Germinability, vigor and electrical conductivity changes in acceleratedly aged watermelon (Citrullus lanatus T.) seeds. Journal of Food, Agriculture and Environment, 2(3-4): 100103.

Amjad, M., Anjum, M.A., 2002. Evaluation of physiological quality of onion seed stored for different periods, International Journal of Agriculture \& Biology, 4(3):365-369

Anonymous, 1999. International Rules for Seed Testing. Seed Science and Technology 24 (supplemental document). International Seed Testing Association (ISTA), Zürich, Switzerland.

Antony, E., Sridhar, K., Kumar, V., 2017. Effect of chemical sprays and management practices on Brachiaria ruziziensis seed, production. Field Crops Research, 211: 19-26.

Arnao, M.B., Hernandez-Ruiz, J., 2006. The physiological function of melatonin in plants. Plant Signaling \& Behavior, 1(3): 89-95.

Bajwa, V.S., Shukla, M.R., Sherif, S.M., Murch, S.J., Saxena, P.K., 2014. Role of melatonin in alleviating cold stress in Arabidopsis thaliana. Journal of Pineal Research, 56(3): 238-245.

Black, M., Bewley, J.D., Halmer, P., 2006. The Encyclopedia of Seeds Science. Technology and Uses, CABI, Oxford.

Borowski, E., Michałek, S., 2006. The effect of seed conditioning on the emergence and early growth of onion and carrot seedlings. Annales Universitatis Mariae Curie-Skłodowska, Sectio EEE, 16: 119129.

Caniş, K., 2006. Origanum husnucan-baseri (Lamiaceae) de tohum çimlenmesinin araştırılması. Yüksek lisans tezi, Akdeniz Üniversitesi Fen Bilimleri Enstitüsü, Antalya.

Chen, Q., Qi, W.B., Reiter, R.J., Wei, W., Wang, B.M., 2009. Exogenously applied melatonin stimulates root growth and raises endogenous indoleacetic acid in roots of etiolated seedlings of Brassica juncea. Journal of Plant Physiology, 166(3): 324-328.

Come, D., Tissaoui, T., 1973. Interrelated Effects of Imbibition, Temperature and Oxygen on Seed Germination. Seed Ecology, London, pp. 157-167.

De Souza, A., García, D., Sueiro, L, Gilart, F., 2014. Improvement of the seed germination, growth and yield of onion plants by extremely low frequency non-uniform magnetic fields. Scientia Horticulturae, 176: 63-69.

Farooq, M., Aziz, T., Rehman, H., Rehman, A., Cheema, S.A., Aziz, T., 2011. Evaluating surface drying and re-drying for wheat seed priming with polyamines: effects on emergence, early seedling 
growth, and starch metabolism. Acta Physiologia Plantarum, 33(5): 1707-1713.

Fenner, M., 2000. Seeds: The Ecology of Regeneration in Plant Communities. Wallingford, UK: CABI Publishing.

Frankenberger, W., Arshad, M., 1991. Yield response of watermelon and muskmelon to L-tryptophan applied to the soil. Horticultural Science, 26(1): 35-37.

Grime, J.P., Mason, G., Curtis, A.V., Rodman, J., Band, S.R., Mowforth, M.A.G., Neal, A.M., Shaw, S., 1981. A comparative study of germination characteristics in a local flora. Journal of Ecology, 69: 1017-1059.

Gulliver, R.L., Heydecker, W., 1973. Establishment of Seedlings in a Changeable Environment. Seed Ecology, London, pp. 433-461.

Hanci, F., Cebeci, E., Mendi, Y.Y., 2012. Effects of $\mathrm{NaCl}$ and $\mathrm{CaCl}_{2}$ on germination performance of some local onion (Allium cepa L.) Cultivars in Turkey. Acta Horticulturae, 960(29): 203-209

Hattori, A., Migitaka, H., Iigo, M., Itoh, M., Yamamoto, K., Ohtani-Kaneko, R., Hara, M., Suzuki, T., Reiter, R.J., 1995. Identification of melatonin in plants and its effects on plasma melatonin levels and binding to melatonin receptors in vertebrates. Biochemistry and Molecular Biology International, 35(3): 627-634.

Hernandez-Ruiz, J., Cano, A., Arnao, M.B., 2005. Melatonin acts as a growth-stimulating compound in some monocot species. Journal of Pineal Research, 39(2): 137-142.

Karaca, A., 2013. Dışarıdan yapılan melatonin uygulamaları ile biberde çimlenme sırasında üşüme stresine karşı toleransın arttırılması. Yüksek lisans tezi, Kahramanmaraş Sütçü İmam Üniversitesi Fen Bilimleri Enstitüsü (Basılmamış), Kahramanmaraş.

Kevseroğlu, K., 1993. Doğal floradan toplanan datura (Datura stramonium L.) tohumlarının çimlenmesine bazı fiziksel ve kimyasal işlemlerin etkisi. Turkish Journal of Agriculture and Forestry, 17: 727-735.

Khan, H.A., Ayub, C.M., Pervez, M.A., Bilal, R.M., Shahid, M.A., Ziaf, K., 2009a. Effect of seed priming with $\mathrm{NaCl}$ on salinity tolerance of hot pepper (Capsicum annuum L.) at seedling stage. Soil and Environment, 28: 81-87.

Khan, H.A., Pervez, M.A., Ayub, C.M., Ziaf, K., Bilal, R.M., Shahid, M.A., Akhtar, N., 2009b. Hormonal priming alleviates salt stress in hot pepper (Capsicum annuum L.). Soil and Environment, 28: 130-135.

Khodary, S.E.A., 1992. Effect of salinity and tryptophan on growth and some metabolic changes in wheat and sorghum plants. Biologica Plantarum, 34(5-6): 439-443.

Korkmaz, A., Karaca, A., Kocaçınar, F., Cuci, Y., 2017. The Effects of Seed Treatment with Melatonin on Germination and Emergence Performance of Pepper Seeds under Chilling Stress. Journal of Agricultural Sciences, 23(2): 167-176.

Lerner, A.B., Case, J.D., Takahashi, Y., Lee, T.H., Mori, W., 1958. Isolation of melatonin, the pineal gland factor that lightens melanocytes. Journal of the American Chemical Society, 80(10): 2587-2587.

Li, C.X., Feng, S.L., Shao, Y., Jiang, L.N., Lu, X.Y., Hao, X.L., 2007. Effects of arsenic on seed germination and physiological activities of wheat seedlings. Journal of Environmental Sciences, 19(6): 725-732.

Mercedes, F., Carbonell, M.V., Martinez, E., 2007. Exposure of maize seeds to stationary magnetic fields: Effects on germination and early growth. Environmental and Experimental Botany, 59(1): 6875.

Nawaz, M.A., Huang, Y., Bie, Z., Ahmed, W., Reiter, R.J., Niu, M., Hameed, S., 2016. Melatonin: current status and future perspec- tives in plant science. Frontiers in Plant Science, 6: 1-13.

Nematollah, E., Maryam, H., Najmeh, Z., 2011. Optimizing seed germination threatened endemic species of the Persian shallot (Allium hirtifolium boiss.). African Journal of Agricultural Research, 6(25): 5650-5655.

Palego, L., Betti, L., Rossi, A., Giannaccini, G., 2016. Tryptophan biochemistry: Structural, nutritional, metabolic, and medical aspects in human. Journal of Amino Acids, 1-13.

Parvez, M.A., Muhammad, F., Ahmad, M., 2000. Effect of auxin precursor (L-tryptophan) on the growth and yield of tomato (Lycopersicon esculentum). Pakistan Journal of Biological Science, 3(7): 11541155.

Pimpini, F., Filippini, M.F., Gianquinto, G., 1993. The influence of temperature and light on seed germination of radicchio (Chicorium intybus $\mathrm{L}$. var. silvestre Bishoff). Journal of Seed Science and Technology, 21(1): 69-83.

Posmyk, M., Balabusta, M., Wieczorek, M., Sliwinska, E., Janas, K.M., 2009. Melatonin applied to cucumber (Cucumis sativus L.) seeds improves germination during chilling stress. Journal of Pineal Research, 46(2): 214-223.

Simlat, M., Ptak, A., Skrzypek, E., Warchoł, M., Morańska, E., Piorkowska, E.i 2018. Melatonin significantly influences seed germination and seedling growth of Stevia rebaudiana Bertoni. PeerJ-the Journal of Life and Environmental Sciences, 6: e5009.

Takahashi, T., Kakehi, J., 2010. Polyamines: ubiquitous polycations with unique roles in growth and stress responses. Annals of Botany, 105: 1-6.

Tipırdamaz, R., Gömürgen, A.N., 2000. The effects of temperature and gibberellic acid on germination of Eranthis hyemalis (L.) Salisb. seeds. Turkish Journal of Botany, 24: 143-145.

Tiryaki, İ., Keleş, H., 2012. Reversal of the inhibitory effect of light and high temperature on germination of Phacelia tanacetifolia seeds by melatonin. Journal of Pineal Research, 52(3): 332-339.

Wei, W., Li, Chu, Q.T., Reiter, Y.N., Yu, R.J., Zhu, X.M., Zhang, D.H., Ma, W.K., Lin, B., Zhang, Q., Chen, J.S., 2015. Melatonin enhances plant growth 
and abiotic stress tolerance in soybean plants. Journal of Experimental Botany, 66(3): 695-707.

Zhang, N., Zhao, B., Zhang, H.J., Weeda, S.,Yang, C., Yang, Z.C., Ren, S., Guo, Y.D., 2013. Melatonin promotes water-stress tolerance, lat- eral root formation, and seed germination in cucumber (Cucumis sativus L.). Journal of Pineal Research, 54(1): 15-23.

Zhang, N., Sun, Q., Li, H, Li, X., Cao, Y., Zhang, H., Li, S., Zhang, L., Qi, Y., Ren, S., Zhao, B., Guo,
Y.D., 2016. Melatonin improved anthocyanin accumulation by regulating gene expressions and resulted in high reactive oxygen species scavenging capacity in cabbage, Frontiers in Plant Science, 7: 197.

Zhang, N., Zhang, H., Sun, Q., Cao, Y., Li, X., Zhao, B., Wu, P., Guo, Y., 2017. Proteomic analysis reveals a role of melatonin in promoting cucumber seed germination under high salinity by regulating energy production. Scientific Reports, 7(503): 1-15. 